\title{
CHANGE IN PROPERTIES OF M-10DM MINERAL MOTOR OIL AFTER ITS USING IN THE DIESEL ENGINE
}

\author{
Oleg Hrynyshyn ${ }^{1,}{ }^{*}$, Bogdan Korchak ${ }^{1}$, Taras Chervinskyy ${ }^{1}$, Viktoria Kochubei ${ }^{1}$
}

https:

\begin{abstract}
Physico-chemical properties and group composition of the virgin and used M-10DM motor oil for diesel engines were studied. IR-spectroscopy and derivatography were used for investigation. By means of $\mathrm{X}$-ray fluorescence the composition of inorganic part was determined. Change in properties and composition of $\mathrm{M}$ 10DM before and after using are discussed.
\end{abstract}

Keywords: mineral motor oil, used oil, group composition, oil aging.

\section{Introduction}

During operation the motor oils lose their initial performance characteristics. The irreversible change in time of motor oils properties leads to deterioration of lubricating properties, wear of engine parts and reduction of the overhaul period. This phenomenon is called "aging" and involves chemical, thermal and mechanical processes. However, the phenomenon as itself is still controversial and not fully understood [1-3].

In [4] the aging process of oils is discussed from the operational, mechanical and thermo-chemical points of view. It is shown that different samples of oil provided contradictory results of conventional test methods and the possibility of their use as criteria for evaluating oils serviceability is critically examined.

A. Chudinovskykh [5] developed a theory that allows motor oil to be considered as an element of combustion engine design. Taking this fact as a basis he developed the mathematical dependence between engine reliability and oil properties, which allows to calculate the oil suitability like any mechanical part of the engine. He proposed the models of motor oils aging allowing to predict by calculations the formation of low- and hightemperature deposits in the engine and wear of its individual parts and components without inspection, i.e. the models allow to interpret the oil state in a way that

\footnotetext{
${ }^{1}$ Lviv Polytechnic National University

12, S.Bandery St., 79013 Lviv, Ukraine

*hrenik@yandex.ru

(C) Hrynyshyn O., Korchak B., Chervinskyy T., Kochubei V., 2017
}

ensures its compatibility with the change of construction elements.

The performance properties of oil are significantly affected by the engine operation mode. The authors [6] examined the influence of climatic regime on motor oil aging. It was found that after finishing service life of oil the climatic regime has a minor effect on the aging mechanism. But in winter the oil aging is more intense due to moisture condensation when starting engine operation, resulting in saponification of additives.

In Ref. [7] the principles of adsorption and chemisorption intensity of motor oils active components are examined. It was found that oil molecules decomposition occurs before the oxidation not only during operation, but also during storage. The decomposition may cause changes in physical and chemical properties of lubricating medium. The mechanical and thermal decomposition of lubricant liquid components is determined by their average molecular weight and chemical structure. In addition, the destruction of lubricants is accelerated by a catalytic action of water and metal and progresses rapidly with increasing temperature.

The authors [8] investigated the changes in the fractional composition of oil during its operation. It was established that the reaction occurs in the molecules of biand tricyclic naphthenic hydrocarbons with the formation of mono- and bicyclic naphthenic hydrocarbons, respectively, which in their turn, convert into unstable monocyclo-, cyclodiolefinic and aromatic hydrocarbons via dehydrogenation reactions. It was proven that the condensation reaction of volatile hydrocarbons provides the reduction of basic components in oil and increase of aromatic and asphalt-resinous substances.

A. Khaziev et al. [9] describe the main principles and possibilities of motor oils analysis using IRspectroscopy to examine the change in oil composition during operation.

However, the present literature data are incomplete and do not allow to describe systematically the aging process of concrete types of petroleum oils, namely mineral oils for diesel engines, which are the most popular oils. The investigation of the mentioned oils properties after their usage in the engines will give the possibility to 
establish the reasons and mechanism of oil aging. Moreover, the obtained results may be used to choose the optimal technology of used oils recycling.

The aim of the present work is to study the properties of virgin and used M-10DM oil and to determine the possible reasons of its aging.

\section{Experimental}

For investigations we selected M-10DM mineral oil, which is widely used for farm tractors. The samples before using in the augmented diesel engine and after finishing standard service life (approximately 350 motor hours) of oil were studied.

The density of the samples was determined picnometrically, the refraction index - using a refractometer, viscosity - using a viscosimetry method, flash point in the device of the open type [10]. Group hydrocarbon composition was studied by a chromatography. The silica alumina gel of ASK type was used as an adsorbent. Fractions of hydrocarbons were washed out by petroleum ether and benzene, and asphalt-resinous substances were desorbed by alcohol-benzene mixture.

Investigation of thermal stability of oil samples was performed on a derivatograph Q-1500D (Paulik-PaulikErdey system) with the registration of the analytical signal of mass loss and heat effects using a computer. The samples were analyzed under a dynamic mode with a heating rate of $10 \% \mathrm{~min}$ in the air. The weight of the samples was $100 \mathrm{mg}$. The reference substance was aluminum oxide.

$\mathrm{X}$-ray fluorescence was used to determine the elemental composition of oils and was carried out using a mobile precision analyzer EXPERT 3L, the assignment of which is to determine the mass fraction of chemical elements in monolithic and homogeneous powder objects. For the analysis we prepared oil samples, which were burned at $723 \mathrm{~K}$ for $4 \mathrm{~h}$, cooled in a desiccator and grinded.

IR spectroscopy was performed on Spectrum Two FT-IR spectrometer of PerkinElmer firm in the cell made of zinc selenide with $0.1036 \mathrm{~mm}$ of thicknes. We used the program Spectrum v.10.03.06.

\section{Results and Discussion}

The experimental results concerning physicochemical properties are represented in Table 1.

The used oil has a lower viscosity and viscosity index compared with the virgin one. The reason is some amount of diesel fuel which transfers into oil during engine operation. The increase in a flash point value confirms this fact. Moreover, the group composition of oil was changed. It is confirmed by the change of refractive index and specific refraction values. Coking ability increases, obviously due to the group composition change. The water and mechanical additives content are also increased in the used oil.

If we analyze the changes in the group composition (Table 2), we observe the decrease in the amount of paraffin-naphthenic hydrocarbons and increase of monocyclic aromatics and tarry asphaltene substances for the used oil. It means that during operation the destruction of paraffin hydrocarbons, dehydration of naphthenic hydrocarbons and condensation of aromatic hydrocarbons take place leading to the formation of tarry asphaltene substances. Such conclusion is confirmed by the increase in coking ability and refractive index values and the decrease in the value of viscosity index.

Table 1

\section{Physico-chemical properties of M-10DM oil}

\begin{tabular}{|l|c|c|}
\hline \multicolumn{1}{|c|}{ Index } & Virgin oil & Used oil \\
\hline Viscosity, $\mathrm{mm}^{2} / \mathrm{s}:$ & & 51.65 \\
- at $323 \mathrm{~K}, \mathrm{v}_{50}$ & 60.13 & 10.22 \\
- at $373 \mathrm{~K}, \mathrm{v}_{100}$ & 11.40 & 5.05 \\
$-\mathrm{v}_{50} / \mathrm{v}_{100}$ & 5.27 & 88 \\
\hline Viscosity index & 95 & 0.14 \\
\hline Density, $\mathrm{kg} / \mathrm{m}^{3}$ & 889 & 0.062 \\
\hline Water content, $\%$ & сліди & 2.30 \\
\hline Mechanical additives content, $\%$ & 0.029 & 1.4940 \\
\hline Coking ability, $\%$ & 1.44 & 0.3098 \\
\hline Refractive index, $\mathrm{n}_{\mathrm{D}}{ }^{20}$ & 1.4900 & 254 \\
\hline Specific refraction & 0.2917 & 488 \\
\hline Freezing point, K & 253 & 2.71 \\
\hline Flash point, K & 503 & - \\
\hline Acid number, $\mathrm{mg} \mathrm{KOH} / \mathrm{g}$ & 1.30 & \\
\hline Base number, $\mathrm{mg} \mathrm{KOH} / \mathrm{g}$ & 5.83 & \\
\hline
\end{tabular}


Group composition of M-10DM oil

\begin{tabular}{|l|c|c|}
\hline \multicolumn{1}{|c|}{ Group } & Virgin oil & Used oil \\
\hline Paraffin-naphthenic hydrocarbons & 75.2 & 71.0 \\
\hline Aromatic monocyclic hydrocarbons & 5.6 & 10.7 \\
\hline Aromatic bicyclic hydrocarbons & 15.7 & 14.2 \\
\hline Aromatic polycyclic hydrocarbons & 1.9 & 1.2 \\
\hline Tarry asphaltene substances & 1.6 & 2.9 \\
\hline
\end{tabular}

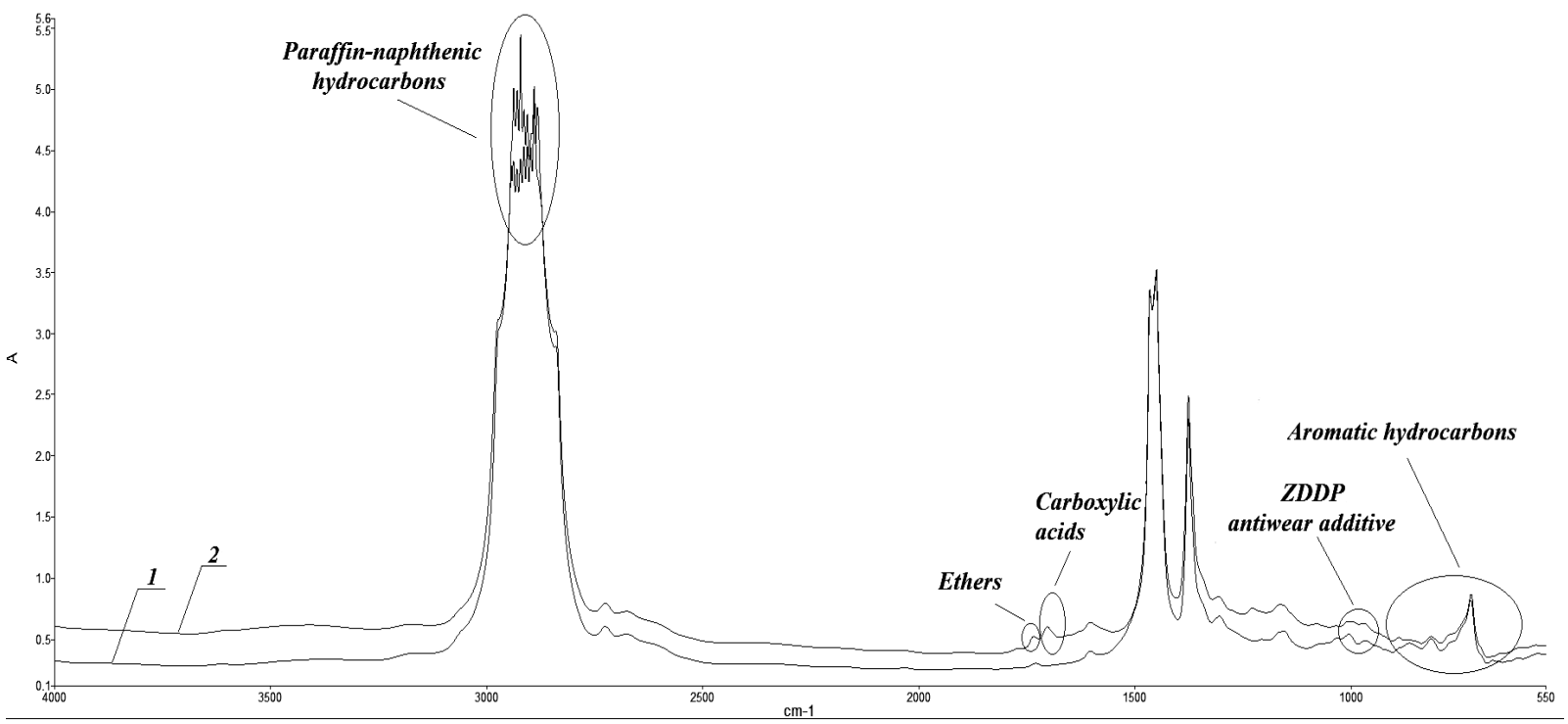

Fig. 1. IR-spectra of the virgin (1) and used (2) oil M-10DM

The analysis of IR-spectra of the virgin and used oils confirms the results about group composition and allows to identify the products of oil aging (Fig. 1).

The products of aging which are formed and stored during oil operation are alcohols, aldehydes, ketones, organic acids, etc. The presence of the mentioned products with $\mathrm{C}=\mathrm{O}$ group in the used oil is confirmed by absorption bands at $1740-1690 \mathrm{~cm}^{-1}$. At the same time they are absent in the spectrum of the virgin oil. Carboxylic acids in the used oil were identified by the absorption bands at $1720-1680 \mathrm{~cm}^{-1}$ (in the virgin oil they are absent). The high value of acid number for the used oil also confirms this fact (Table 1).

The presence of esters as the products of oil aging is confirmed by the absorption bands at $1740-1730 \mathrm{~cm}^{-1}$ typical of $\mathrm{C}=\mathrm{O}$ groups of aliphatic esters, as well as by the bands at $1235-1225 \mathrm{~cm}^{-1}$ typical of stretching vibrations of $\mathrm{C}-\mathrm{O}$ bond. IR-spectrum of the virgin oil does not have the mentioned bands indicating the absence of esters in the virgin oil.

The asymmetric stretching vibrations of $\mathrm{C}-\mathrm{O}-\mathrm{C}$ group, which are typical of ethers, are present in the spectrum of the used oil in the area of $1125-1025 \mathrm{~cm}^{-1}$. In the spectrum of the virgin oil we did not observe these vibrations.

For the virgin oil the absorption band in the area of $1020-960 \mathrm{~cm}^{-1}$ corresponds to ZDDP antiwear additive.
The intensity of the same band in the spectrum of the used oil is less indicating the depletion of the additive.

To establish the change in thermal stability of M10DM we carried out derivatographic investigations before and after engine operation. According to the results of thermogravimetry (TG), differential thermogravimetry (DTG) and differential thermal analysis (DTA) of the virgin and used oils the thermolysis takes place over two or three stages, respectively (Table 3, Figs. 2-3).

Thermolysis of the virgin oil (Fig. 2) takes place over three stages. The first stage, when the sample looses the main mass $(\Delta m=87.20 \%)$ is within the temperature range of 293-663 K. This stage is accompanied by the appearance of intense exothermal effect on DTA curve with the maximum at $620 \mathrm{~K}$ and corresponds to a thermooxidative destruction of hydrocarbons and their partial combustion. The second stage is within the range of $663-850 \mathrm{~K}$. It is accompanied by the appearance of the next exothermal effect on DTA curve with the maximum at $767 \mathrm{~K}$ and corresponds to the combustion of pyrolytic residue $(\Delta m=11.45 \%)$. At the third stage of thermolysis within 850-998 K the combustion of carbonized residue takes place. This process is accompanied by a slight mass loss $(\Delta m=1.35 \%)$ and appearance of the third exothermal effect on DTA curve with the maximum at $913 \mathrm{~K}$. 
Table 3

Thermal investigations of M-10DM oil

\begin{tabular}{|c|c|c|c|c|}
\hline Sample & Stage & Temperature range, K & Mass loss, $\%$ & Maximum exothermal effect, K \\
\hline \multirow{3}{*}{ Virgin oil } & I & $293-663$ & 87.20 & 620 \\
\cline { 2 - 5 } & II & $663-850$ & 11.45 & 767 \\
\cline { 2 - 5 } & III & $850-998$ & 1.35 & 913 \\
\hline \multirow{2}{*}{ Used oil } & I & $293-660$ & 89.47 & 604 \\
\cline { 2 - 5 } & II & $660-923$ & 10.53 & 752 \\
\hline
\end{tabular}

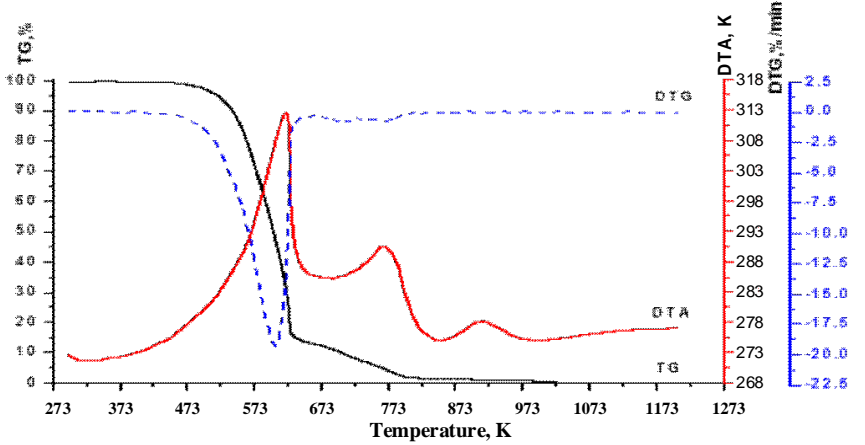

Fig. 2. Thermogram of the virgin oil

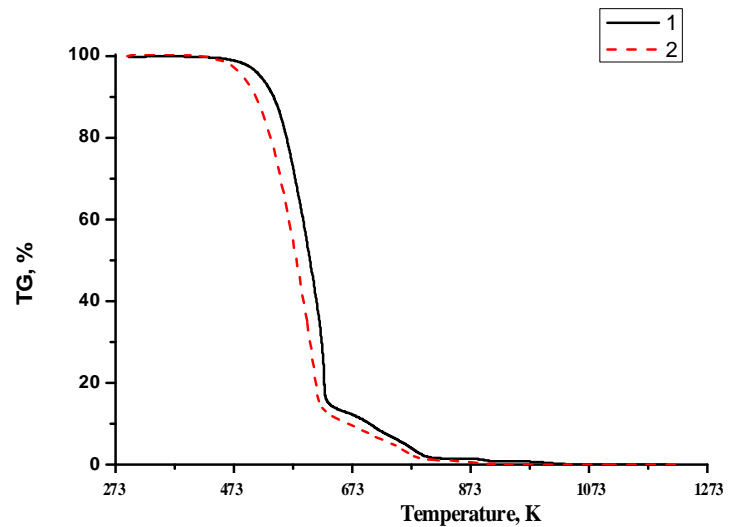

Fig. 4. TG curves of M-10DM: virgin oil (1); used oil (2)

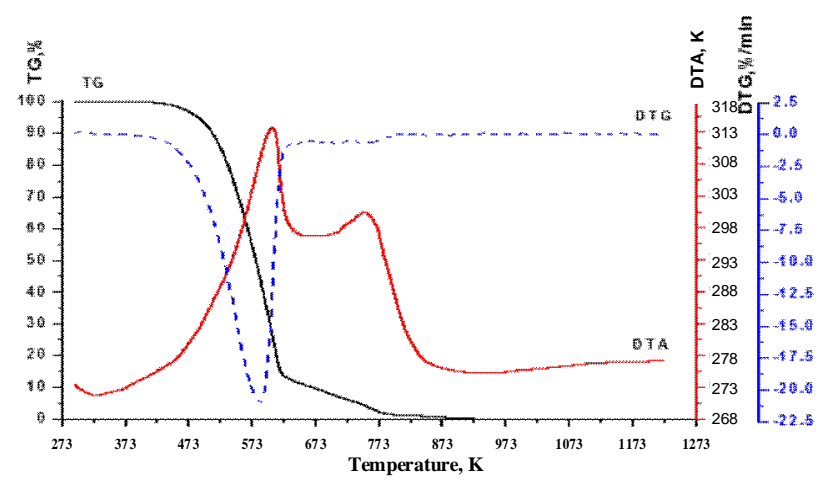

Fig. 3. Thermogram of the used oil

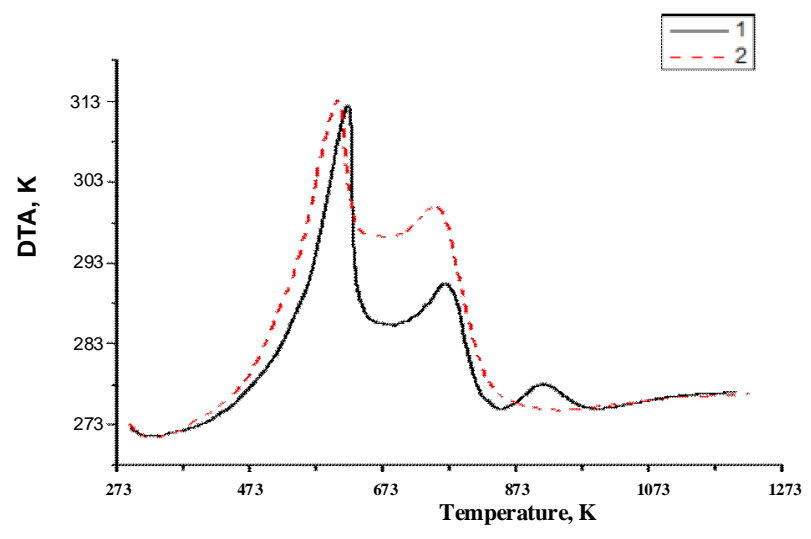

Fig. 5. DTA curves of M-10DM: virgin oil (1); used oil (2)

Table 4

Elemental composition of M-10DM inorganic part

\begin{tabular}{|c|c|c|}
\hline \multirow{2}{*}{ Element } & \multicolumn{2}{|c|}{ Content, ppm } \\
\cline { 2 - 3 } & in the virgin oil & 2950.99 \\
\hline $\mathrm{P}$ & 1024.34 & 6166.21 \\
\hline $\mathrm{S}$ & 2383.09 & 16006.38 \\
\hline $\mathrm{Ca}$ & 7561.90 & 53.79 \\
\hline $\mathrm{Ti}$ & 13.82 & 7.09 \\
\hline $\mathrm{Mn}$ & 1.92 & 307.10 \\
\hline $\mathrm{Fe}$ & 10.34 & 4033.07 \\
\hline $\mathrm{Zn}$ & 1021.58 & 4.14 \\
\hline $\mathrm{Sr}$ & 1.32 & - \\
\hline $\mathrm{Zr}$ & 0.12 & 1.48 \\
\hline $\mathrm{Mb}$ & 0.36 & 26.90 \\
\hline
\end{tabular}


Thermolysis of the used oil (Fig. 3) takes place over two stages. The first stage corresponds to the thermooxidative destruction of the sample and partial combustion of destruction products $(\Delta m=89.47 \%$, temperature range $293-660 \mathrm{~K}$ ). The first exothermal effect appears on DTA curve with the maximum at $604 \mathrm{~K}$. At the second stage within $660-923 \mathrm{~K}$ the complete combustion of pyrolytic residue takes place $(\Delta m=10.53 \%)$ and the second exothermal effect has the maximum at $752 \mathrm{~K}$.

It should be noted that the used oil has a lower thermal stability compared with that of the virgin oil. The reason is the decrease in additives amount. While heating the used oil loses its mass more intensive than the virgin oil (Fig. 4) and maxima of its exothermal effects are shifted to the area of lower temperatures (Fig. 5). The combustion of pyrolytic residue takes place over one stage for the used oil and is accompanied by the appearance of only one exothermal effect. The combustion of pyrolytic residue of the virgin oil takes place over two stages within wider temperature range (663-998 K). Two exothermal effects appear on DTA curve.

As a result of engine operation there are following changes in the used oil: depletion of additives presented in the virgin oil; accumulation of some inorganic compounds due to the partial combustion of oil and adding new portions of virgin oil; getting the wear and tear products into motor oil. The extreme increase of metal content in the oil is one of the reasons of their periodical change [11].

It is known that apart from hydrocarbons and tarry asphaltene substances the commercial motor oils contain insignificant amount of inorganic compounds. Their content in the oil is provided by the additives used to improve the oil quality, and as a result of engine operation. X-ray fluorescence was used to investigate the virgin and used oils (Table 4).

\section{Conclusions}

We examined the changes in operational properties and group composition of the virgin and used oil M$10 \mathrm{DM}$ for diesel engines. The decrease in the amount of paraffin-naphthenic hydrocarbons and increase of aromatic hydrocarbons, as well as tarry asphaltene substances were observed. IR-spectroscopy confirmed the formation of oxygen-containing compounds as oil aging products during oil usage. According to derivatographic investigations thermal stability of the used oil was found to be lower comparing with the virgin oil. The composition of inorganic part of the used motor oil differs from that of the virgin oil. This fact is explained by depletion of additives; getting the wear and tear products into motor oil; adding new portions of virgin oil to support the necessary level.

\section{References}

[1] Aulin V., Lysenko S., Kuzyk O.: Konstruiuvannia, Vyrobnytstvo ta Ekspluatatsiia Silskohospodarskykh Mashyn, 2009, 39, 274.

[2] Dominquez-Rosado E., Pichtel J.: Proceed. Indiana Acad. Sci., 2003, 112, 109.

[3] Shostakivskyi I., Paraiko Yu.: Rozvidka ta Rozrobka Naftovykh i Hazovykh Rodovyshch, 2004, 4, 150.

[4] Aulin V., Slon' V., Kuzyk O.: Zbirnyk Nauk. Prac Kirovograd. Techn. Univ., 2012, 25, 98.

[5] Chudinovskykh A.: Doct. thesis, Ros. Univ. Nefti i Gaza, Moskva 2016.

[6] http://conf.sfu-kras.ru/sites/mn2013/section076.html

[7] Bialiakovych O.: Visnyk Nats. Transport. Univ., 2010, 21, 40.

[8] Kuznetsova O., Netreba Zh.: Technol. Audit i Rezervy Proizvodstva, 2015, 23, 64.

[9] Khaziev A., Sugatov N., Petuchov M.: Transport. Transportnye Soorugeniia. Ecologia, 2014, $2,97$.

[10] Isahuliants V., Egorova G.: Khimiia Nefti. Khimiia, Moskva 1965.

[11] Kolodiazhnyi A., Kovalchuk T., Korovin Yu., Antonovych V.: Metody i Obiekty Khim. Analys., 2006, 1, 90.

Received: December 14, 2016 / Revised: M arch 04, 2017 / Accepted: M arch 25, 2017

\section{ЗМІНА ВЛАСТИВОСТЕЙ МІНЕРАЛЬНОЇ МОТОРНОЇ ОЛИВИ М-10ДМ ПІСЛЯ ВИКОРИСТАННЯ ІІЇ У ДИЗЕЛЬНОМУ ДВИГУНІ}

Анотація. Вивчено фізико-хімічні властивості та груповий склад свіжої та відпрацьованої мінеральної моторної оливи М-10ДМ для дизельних двигунів. Наведено результати ІЧ-спектроскопічного та дериватографічного досліджень ции олив. За допомогою рентгенофлуоресиентного методу встановлено склад неорганічної частини олив. Описано зміни складу і властивостей оливи М-10ДМ до та після експлуатаиії в двигуні внутрішнього згоряння.

Ключові слова: мінеральна моторна олива, відпрацьована олива, груповий склад, старіння оливи. 